\title{
Effects of Zoospore Concentration and Application Pressure on Foliage Blight of Catharanthus roseus Caused by Phytophthora nicotianae
}

\author{
T. J. Banko, P. A. Richardson, and C. X. Hong, Virginia Tech, Hampton Roads Agricultural Research and Exten- \\ sion Center, Virginia Beach 23455
}

\begin{abstract}
Banko, T. J., Richardson, P. A., and Hong, C. X. 2006. Effects of zoospore concentration and application pressure on foliage blight of Catharanthus roseus caused by Phytophthora nicotianae. Plant Dis. 90:297-301.

This study investigated the effects of inoculum concentration, application pressure, use of carbon dioxide $\left(\mathrm{CO}_{2}\right)$, and agitation associated with passage through a spray nozzle on zoospore survival and on foliage blight caused by Phytophthora nicotianae. In a greenhouse experiment, plants of Catharanthus roseus were inoculated by spraying zoospore suspensions at pressures of 210,420 , and $630 \mathrm{kPa}\left(30,60\right.$, and $90 \mathrm{lbs} / \mathrm{in}^{2}$ [psi]). A low-pressure 35-kPa (5-psi) control inoculation was provided with a hand-operated aspirator-type mister. There was a consistent reduction in level of disease with increased application pressure, regardless of the zoospore concentration. To determine the source of this disease reduction, laboratory assays were conducted. Zoospore suspensions were pressurized to 210,420 , and $630 \mathrm{kPa}$ with $\mathrm{CO}_{2}$ or air, then transferred from the pressure bottle into a flask by either spraying or pouring. From the flask, the suspensions were spread over plates of PARP-V8 agar and incubated for $72 \mathrm{~h}$, at which time total colony numbers were recorded. $\mathrm{CO}_{2}$ significantly reduced zoospore survival. Pressure strength and method of spore transfer out of pressure bottles also impacted survival to lesser extents. There were significant interactions between pressure source and means of spore suspension transfer, and between pressure strength and means of spore transfer. These results may lead to development of alternative methods of water decontamination to prevent inoculum from entering crop systems through irrigation water.
\end{abstract}

Additional keyword: aeration

Recycling irrigation water is critical for many nursery and greenhouse producers to conserve water and to reduce the release of pollutants into the environment. This practice, unfortunately, concentrates some destructive pathogens in irrigation system retention ponds, making these systems increasingly important as sources of inoculum for plant pathogens (16), in particular of Phytophthora spp. (1,4,15,20,21,27), which are serious pathogens of many nursery crops (3).

Various methods have been used for disinfesting irrigation water, but each has its limitations (16,18). Slow sand filtration has reduced inoculum in recycling systems; however, high maintenance costs, large area requirements (32), and reduced efficiency with increasing flow rates (26) make its practicality questionable for large nurseries. Ozonation has reduced levels of waterborne plant pathogens, but prolonged treatment times limit the quantity of water that can be disinfested (35). Ultraviolet

Corresponding author: C. Hong

E-mail: chhong2@vt.edu

Accepted for publication 29 September 2005.

DOI: 10.1094/PD-90-0297

(C) 2006 The American Phytopathological Society irradiance has reduced pathogenic bacteria $(10,25)$ and pythiaceous fungi $(6)$ in irrigation water, although effectiveness was reduced with increasing flow rates and suspended organic solids $(6,9,10)$. Chlorination is a relatively economical method of water disinfestation and its use in the nursery industry has become widespread (18). However, recycled nursery irrigation water frequently contains large amounts of organic and inorganic solids, increasing chlorine demand, the amount of chorine consumed by oxidizable substances in the water (33). This results in a corresponding reduction in efficacy of the chlorination treatment (21). Stanghellini and Tomlinson (30) demonstrated lysis of zoospores, a major propagule involved with pathogen movement for Phytophthora and Pythium spp. (24,29-31), with nonionic surfactants. Lysis of these zoospores, which lack a cell wall, was due to a disruption in the integrity or permeability of the plasma membrane (30). Other structures of zoosporic fungi that possess a cell wall (hyphae, encysted zoospores, and sporangia) were unaffected by the surfactants (30). Control of cucumber root rot by lysis of Pythium aphanidermatum zoospores (29) and control of root rot of pepper by lysis of Phytophthora capsici zoospores (28) with the addition of nonionic surfactants to recirculating hydroponic systems also has been demonstrated. Lysis of Phytophthora zoospores also has been achieved by modifying the ammonia to calcium ratio in the culture medium (13). These studies demonstrate the relative fragility of zoospores as opposed to other pathogenic propagules with cell walls, and raise the possibility of utilizing certain physical treatments to inactivate zoospores in a recycling irrigation system.

Heald and Johnson (14) reported that pathogenic nematodes pumped through a sprinkler irrigation system from an infested pond became incapable of infecting susceptible plants. They speculated that this may have been due to the pressure exerted at the pump or at the sprinkler orifice. The effects of hydrostatic pressure on microorganisms have been assessed extensively with regard to preservation of foods. The majority of these studies are conducted at pressures generally in the range of 100 to $600 \mathrm{MPa}(14,500$ to 87,000 lbs/in ${ }^{2}$ [psi]) (19), much higher than would be feasible for nursery irrigation systems, which usually are capable of operating at pressures of less than $1 \mathrm{MPa}(<145 \mathrm{psi})$. The application of high pressure may be more critical for inactivating durable bacterial or fungal spores $(12,22,23)$ than zoospores of Phytophthora or Pythium spp. that have no cell wall. Pythiaceous zoospores could be more susceptible to damage or inactivation at much lower pressures. This hypothesis may explain inconsistent success when inoculating plants with zoospores of Phytophthora nicotianae applied under pressure in our laboratory. This study was undertaken to investigate pressures and related stresses within the range of nursery irrigation systems, with regard to their effects on zoospore survival and Phytophthora disease.

\section{MATERIALS AND METHODS}

Greenhouse experiment. These experiments were to determine the effects of zoospore concentration and application pressure on Phytophthora disease.

Inoculum preparation. The inoculum was prepared from a $P$. nicotianae isolate originally obtained from Catharanthus roseus. A 2-week-old culture of this isolate on V8 agar was cut into small pieces and incubated in $1 \%$ chilled sterile soil water extract (SSWE) for $4 \mathrm{~h}$ to produce a spore suspension (17). The suspension was filtered through eight layers of cheesecloth to remove the agar pieces and mycelium 
fragments. Zoospores were counted after vortexing an aliquot of the suspension for $1 \mathrm{~min}$ at high speed. The suspension then was adjusted with SSWE to required zoospore concentrations for inoculation.

Host. Four 3-week-old seedlings of annual vinca $(C$. roseus cv. Little Bright Eye in the first two experiments and Little Mix, a mixture of Little Pinkie, Bright Eye, Coquette, and Delicata, in the third experiment) were potted in a pine bark medium in 2-liter containers and top dressed with $6 \mathrm{~g}$ of Osmocote 14N-6.2P-11.6K (Scotts, Marysville, $\mathrm{OH}$ ) per pot. Plants were grown in a glass greenhouse under natural photoperiod and irradiance with day and night temperatures of $29 \pm 5$ and $21 \pm 5^{\circ} \mathrm{C}$, respectively, and irrigated as needed. Days were $14 \mathrm{~h}$ and $38 \mathrm{~min}$ long.
Inoculation and experimental design. Two concentrations of 2 and $5 \times 10^{3}$ zoospores/ml and four pressures of 35,210 , 420 , and $630 \mathrm{kPa}$ (equivalent to 5, 30, 60, and $90 \mathrm{psi}$ ) were included in the first experiment initiated in July 2002. Inoculum was applied to foliage of test plants using a carbon dioxide $\left(\mathrm{CO}_{2}\right)$-pressurized sprayer at pressures of 210,420 , and $630 \mathrm{kPa}$ through a spray wand fitted with a TXVS8 cone jet nozzle (R\&D Sprayers, Opelousas, LA). It also was applied to control plants at very low pressure (approximately $35 \mathrm{kPa}$ ) with a hand-operated aspiratortype sprayer. The inoculum suspension was applied at a volume of approximately $3.75 \mathrm{ml} /$ pot with four plants/pot. Applications were made in the order of 210,420 , and $630 \mathrm{kPa}$, followed by the $35-\mathrm{kPa}$ hand-
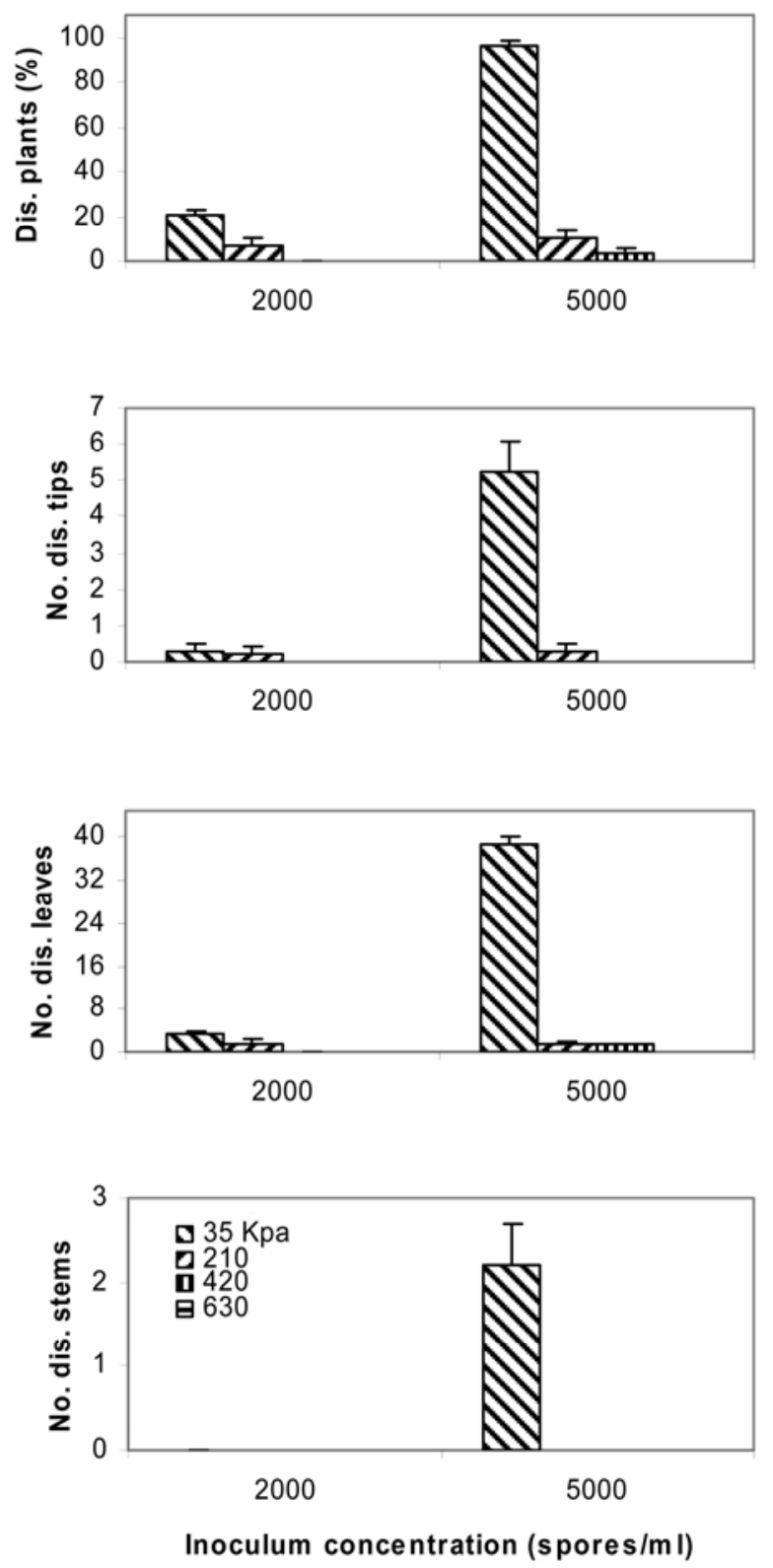

Fig. 1. First greenhouse experiment (July). Effects of zoospore concentration and application pressure on incidence of foliage blight of Catharanthus roseus cv. Little Bright Eye caused by Phytophthora nicotianae in a greenhouse. Vertical bars represent standard error of the means for each pressure level and inoculum concentration tested.

sprayed treatment. After inoculation, the plants were placed overnight in a polyethylene-covered humid tent within the greenhouse. The following morning plants were placed back on greenhouse open benches.

After 3 days, plants were evaluated for disease by counting the number of diseased leaves, shoot tips, and stems, and the number of plants showing disease symptoms on any plant part. A randomized complete block design was utilized, with six replications of three pots per treatment per replication.

A second experiment was conducted in September using inoculum concentrations of 1,2 , and $5 \times 10^{3}$ zoospores $/ \mathrm{ml}$. Inoculum was applied in the same manner and at the same pressures and sequence described for the first (July) experiment. The experiments were analyzed as factorials using analysis of variance (Proc ANOVA; SAS Institute, Cary, NC).

A third experiment was conducted at the same time as the second experiment using an inoculum of $10^{3}$ zoospores $/ \mathrm{ml}$ applied to Catharanthus 'Little Mix'. Applications were made at the same pressures and sequence as described for the first experiment. A randomized complete block design was used, with six replications of three pots per treatment. Plants were evaluated 4 days after inoculation. Data were analyzed using Proc ANOVA.

Laboratory assays. In the first assay, three factors were tested: (i) pressure strength (psi; 35, 210, 420, or $630 \mathrm{kPa}$ ), (ii) source of pressure (SP; $\mathrm{CO}_{2}$ and atmospheric air delivered by a pump; Welch Vacuum, Skokie, IL), and (iii) method of transfer (MT; pouring or spraying from the plastic pressurized bottle). Factorial designs were used to test all individual factors and interactions on zoospore survival. Suspensions of $P$. nicotianae at $10^{3}$ zoospores/ml were transferred to a 2-liter plastic pressure bottle (R\&D Sprayers, Opelousas, LA) in 125-ml aliquots and subjected for $1 \mathrm{~min}$ to pressures of 210 , 420 , or $630 \mathrm{kPa}$ provided by either $\mathrm{CO}_{2}$ from a $\mathrm{CO}_{2}$ pressure tank or air from a Welch pump. The pressurized zoospore suspension either was sprayed from the pressure bottle through a spray nozzle (TXVS-8 cone jet) into a glass flask or the pressure was released and the suspension was poured into the flask. All bottles, flasks, and spray equipment used were thoroughly rinsed with deionized water between treatments to eliminate zoospores from the previous treatment. The $35-\mathrm{kPa}$ pressure spray treatment was sprayed into the flask using a hand-operated aspirator mister. From the glass flask, a 200- $\mu$ aliquot of treated spore suspension was spread in each of three $10-\mathrm{cm}$ petri dishes with PARP-V8 agar (11) with some modifications (5\% clarified V-8 juice plus $15 \mathrm{~g}$ of Bacto agar/liter, autoclaved, then cooled to $50^{\circ} \mathrm{C}$ before adding stocks to obtain 
concentrations per liter of Rifamycin SV, $10 \mathrm{mg}$; benomyl, $10 \mathrm{mg}$; ampicillin, 250 $\mathrm{mg}$; pentachloronitrobenzene, $100 \mathrm{mg}$; and pimaricin, $10 \mathrm{mg}$ ). Untreated portions of the zoospore suspension were similarly spread over agar plates for control spore counts. The agar plates were incubated at room temperature in the dark. Emerging colonies were marked at 24,48 , and $72 \mathrm{~h}$, with total number of colonies per plate recorded at $72 \mathrm{~h}$. The experiment was repeated once. Colony count data were analyzed using the Proc ANOVA procedure.

A second test was performed to measure any change in survivability from the start to the completion of the first assay. A 200$\mu \mathrm{l}$ aliquot of the spore suspension was spread in each of three petri dishes containing the PARP-V8 agar before any treatments were initiated and after all of the treatments were completed. The amount of time elapsed between the start and end of the tests was approximately $1 \mathrm{~h}$.

A third test was done to determine whether rinsing the sprayer before starting a treatment impacted pathogen recovery. This was accomplished by utilizing only the treatments involving pressurized spray delivery at the highest air pressure $(630$ $\mathrm{kPa}$ ) without rinsing and after thoroughly rinsing the sprayer unit. The sprayed suspensions were sampled and plated as described above. The plates were incubated and colonies counted for both tests as described above for the first assay and data were analyzed using the Proc ANOVA procedure.

\section{RESULTS}

Greenhouse experiment. In the July experiment, there was a significant spore number-inoculation pressure interaction for percentage of diseased plants and numbers of diseased leaves, shoot tips, and stems $(P<0.0001)$. This primarily reflects less disease with $2 \times 10^{3}$ spores/ml than with $5 \times 10^{3}$ spores $/ \mathrm{ml}$ when applied at 35 $\mathrm{kPa}$. However, with both inoculum levels, disease is reduced to zero at $630 \mathrm{kPa}$ with increased inoculation pressure (Fig. 1). In the September experiment, response to inoculation at various pressures was similar to that obtained in July, although a greater number of plant organ units were diseased in the September experiment (Fig. 2). A significant spore number-inoculation pressure interaction for all evaluated parameters $(P<0.0001)$ reflected lower disease levels with lower spore counts $\left(10^{3}\right.$ and $2 \times 10^{3}$ spores $/ \mathrm{ml}$ ) than at $5 \times 10^{3}$ spores $/ \mathrm{ml}$ when inoculum was applied at $35 \mathrm{kPa}$ (Fig. 2). At higher inoculation pressures, there was a similar reduction in disease among all three spore levels. Although reduction in disease from 210 to $420 \mathrm{kPa}$ was less in the September than the July experiment, disease reduction was nearly $100 \%$ for most parameters at 630 $\mathrm{kPa}$. Results of the experiment using $C$. roseus with mixed cultivars was consistent with those of the other two experiments with Little Bright Eye. Percent diseased plants decreased linearly $(P=0.008)$ from 56 to $3 \%$ as inoculum application pressure increase from 35 to $630 \mathrm{kPa}$ (data not shown).

Laboratory assays. psi, SP, and MT each significantly impacted zoospore survival (Table 1). MT significantly interacted with psi and SP. Fewer colonies developed from pressurized zoospore suspensions poured than sprayed from pressure bottles for air-pressurized spore suspensions but not for $\mathrm{CO}_{2}$-pressurized suspensions (Ta- ble 2). Substantially fewer colonies were recovered from $\mathrm{CO}_{2}$-pressurized zoospore suspensions than from air-pressurized suspensions when suspensions were sprayed. Zoospore survival generally decreased with increasing pressure from 35 to $210 \mathrm{kPa}$ and from 420 to $630 \mathrm{kPa}$ provided by either $\mathrm{CO}_{2}$ or air. These results are most obvious for spore suspensions transferred out of pressure bottles by spraying (Table 2).

There was no difference in pathogen recovery from zoospore suspension aliquots taken at the beginning of the first assay
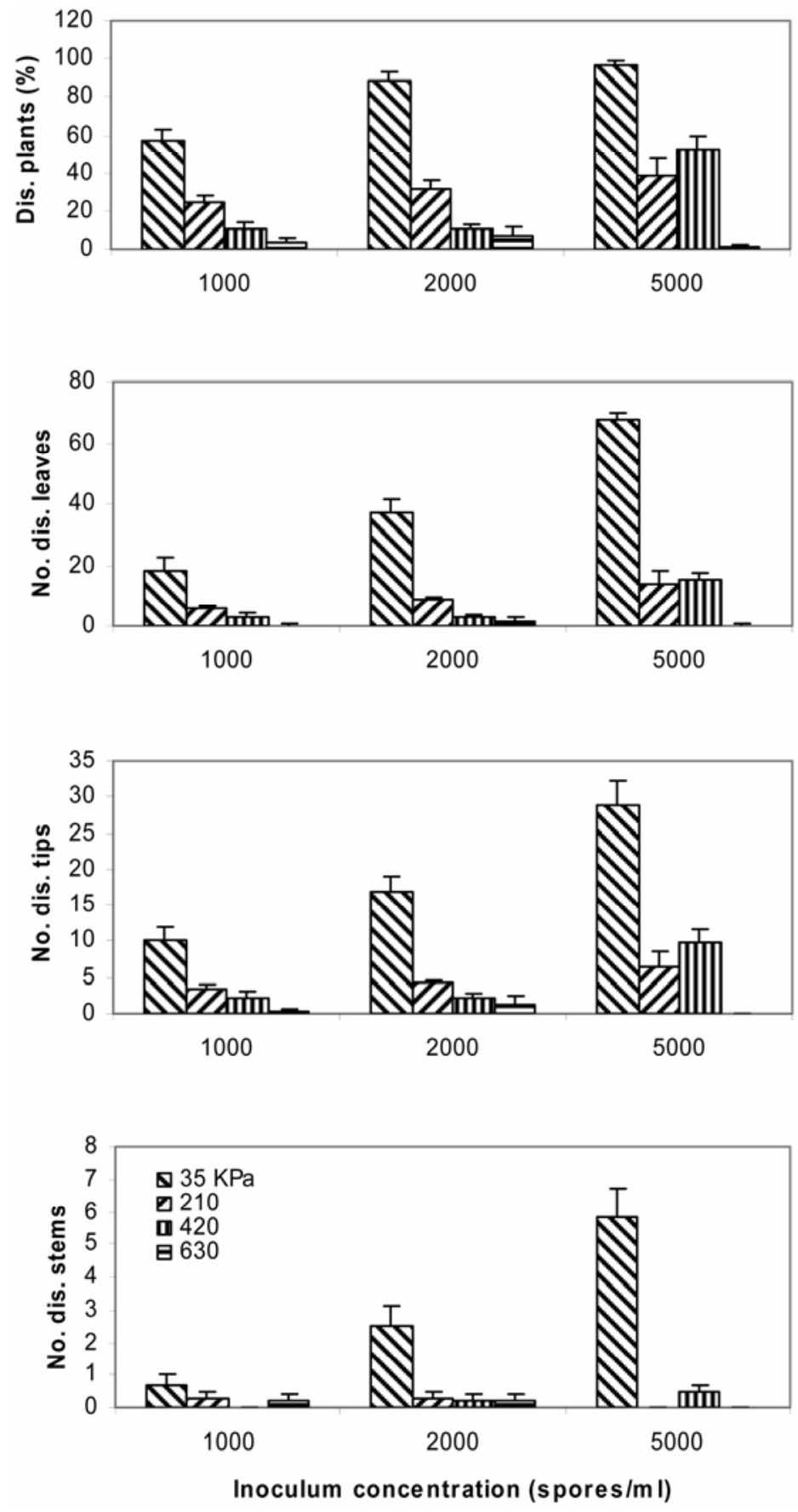

Fig. 2. Second greenhouse experiment (September). Effects of zoospore concentration and application pressure on incidence of foliage blight of Catharanthus roseus cv. Little Bright Eye caused by Phytophthora nicotianae in a greenhouse. Vertical bars represent standard errors for each pressure level and inoculum concentration tested. 
compared with those taken at the end, a of $200 \mu \mathrm{l}$ taken before and after the first assay resulted in 34.7 and 25.3 colonies in the initial test $(P=0.0941)$, and 29.7 and 30.7 colonies in the repeated test $(P=$ 0.8388 ), respectively. These results show that the loss in zoospore survival due to time between the initiation and completion of the major assays was negligible.

Rinsing or not rinsing the sprayer between treatments significantly affected the pathogen recovery. A zoospore suspension of $200 \mu$ produced 24.0 and 49.7 colonies from the rinsed and not rinsed sprayer, respectively, in the initial test $(P=0.0042)$. Similar results (9.7 versus 33.3 colonies) were obtained in the repeated test $(P=$ 0.0155). This shows that rinsing the sprayer between pressure treatments as increasing the accuracy of the results.

\section{DISCUSSION}

Numerous studies have been conducted on utilizing pressures in the field of food preservation, indicating that high pressure is required to disrupt bacterial or fun period of about $1 \mathrm{~h}$. A zoospore suspension described was a necessary procedure for

gal spores with durable cell walls $(12,19,22,23)$. To our knowledge, this study is the first to demonstrate that zoospores of Phytophthora spp. without cell walls are more sensitive to pressure or pressure combined with turbulence or agitation and aeration $\left(\mathrm{CO}_{2}\right.$ or air) than regular bacterial and fungal spores (19). These findings could have significant practical implications.

This study adds a new dimension in understanding the observations that Phytophthora spp. were recovered at greater rates from runoff water entering retention basin than exiting water from the same basins collected at sprinklers $(4,33)$. Zoospores are the major propagule of Phytophthora spp. in irrigation water $(5,24,28,31)$. A portion of these spores may have been inactivated when they were passed through irrigation lines and sprinklers at $420 \mathrm{kPa}$, a hydrostatic pressure commonly used for overhead irrigation at nurseries.

More importantly, this study may lead to the development of alternative methods for water decontamination to reduce the risk of inoculum introduction and dispersal

Table 1. Factorial analysis of CFU of Phytophthora nicotianae from zoospores treated under different pressures, then transferred out of treatment containers by either spraying or pouring

\begin{tabular}{lccc}
\hline & & \multicolumn{2}{c}{$\boldsymbol{P}$ value for two experiments in 2004 } \\
\cline { 3 - 4 } Source & Degree of freedom & 11 February & 25 February \\
\hline Pressure (PSI) & 3 & $<0.0001$ & $<0.0001$ \\
Source of pressure (SP) & 2 & $<0.0001$ & $<0.0001$ \\
Means of transfer (MT) & 2 & $<0.0001$ & $<0.0001$ \\
PSI $\times$ SP & 1 & 1.0000 & 1.0000 \\
PSI $\times$ MT & 2 & $<0.0001$ & $<0.0001$ \\
SP $\times$ MT & 3 & $<0.0001$ & $<0.0001$ \\
PSI $\times$ SP $\times$ MT & 1 & 1.0000 & 1.0000 \\
Error & 2 & $\ldots$ & $\ldots$ \\
\hline
\end{tabular}

a Pressure generated by air or carbon dioxide.

${ }^{\mathrm{b}}$ Zoospore suspension transferred out of treatment container by spraying or pouring.

Table 2. Number of CFU per 10-cm petri dish of Phytophthora nicotianae from zoospores treated under different pressures, then transferred out of treatment containers through spraying or pouring ${ }^{\mathrm{a}}$

\begin{tabular}{lcccc}
\hline & & \multicolumn{2}{c}{ Colonies/dish } & \\
\cline { 3 - 4 } Date, pressure source & Pressure $(\mathbf{k P a})$ & Spray & Pour & LSD \\
\hline February 11, 04 & & & & \\
Air & 35 & 90 & 35 & 9.7 \\
& 210 & 77 & 25 & 13.6 \\
& 420 & 80 & 28 & 5.8 \\
LSD & 630 & 50 & 27 & 12.3 \\
$\mathrm{CO}_{2}$ & $\ldots$ & 10.7 & 6.8 & $\ldots$ \\
& 210 & 28 & 33 & 15.6 \\
LSD & 420 & 24 & 23 & 7.3 \\
February 25, 04 & 630 & 13 & 24 & 9.5 \\
Air & $\ldots$ & 11.1 & 8.8 & $\ldots$ \\
& 35 & 64 & 25 & \\
& 210 & 57 & 22 & 19.3 \\
LSD & 420 & 48 & 16 & 10.2 \\
CO & 630 & 33 & 18 & 21.1 \\
& $\ldots$ & 2.2 & 10.2 & $\ldots$ \\
LSD & 210 & 16 & 15 & 11.3 \\
\hline
\end{tabular}

${ }^{a}$ LSD $=$ least significant difference. through irrigation systems. The greenhouse experiments clearly demonstrated a reduction in Phytophthora blight with increasing inoculum application pressures (Figs. 1 and 2). Although higher spore concentrations resulted in more disease at application pressures $<420 \mathrm{kPa}$, disease incidence was reduced in response to increased application pressures. The percent reduction in disease incidence is proportional to increased application pressure regardless of inoculum concentration. At $630 \mathrm{kPa}$, disease was reduced by 70 to $100 \%$ for all spore concentrations. This suggests a loss of zoospore survival due either directly to the pressure or to another factor or factors associated with pressure. Turbulence or agitation that occurred as the inoculum was forced through a spray nozzle could be one factor affecting zoospore survival. It has been speculated that this type of stress may be responsible for a reduction in the survival and infectivity of plant-pathogenic nematodes discharged through an overhead sprinkler irrigation system (14). Exposure to pressurized $\mathrm{CO}_{2}$ when applied through a pressurized sprayer could be another factor affecting zoospore survival.

The laboratory assays confirmed the effects of source (SP) and strength (psi) of pressure and means of inoculum transfer (MT) on zoospore survival and also demonstrated a significant interaction between psi and MT (Table 1). Although increasing pressure from both air and $\mathrm{CO}_{2}$ resulted in a decrease in spore survival, $\mathrm{CO}_{2}$ produced an additional negative effect that was not caused by air. The poured treatments had fewer colony counts overall than the sprayed treatments, but the response to pressure in terms of reduction in colony numbers with increased pressure was more apparent when the suspensions were sprayed rather than poured from the treatment container. This would suggest that, in addition to pressure and $\mathrm{CO}_{2}$, some factors associated with the process of spraying itself, such as agitation, also were involved.

The laboratory assays also show a significant interaction between SP and MT (Table 1). When the source of pressure was air, there were significantly fewer colonies recovered if the spore suspension was poured compared with sprayed from the pressure bottle at a given pressure (Table 2 ). When the pressure source was $\mathrm{CO}_{2}$, the number of colonies recovered for the pour and spray treatments was very similar within a given pressure, except at the highest pressure $(630 \mathrm{kPa})$, where the spray treatments had lower colony counts. The cause of this response is not known. We hypothesize two possibilities. One is that, following pressurization of the pour treatments, pressure was released rapidly. This rapid decrease in pressure may have caused a substantial number of zoospores to rupture, reducing counts for the pour 
treatments. The other possibility is that agitation due to the spray process may have stimulated the zoospores to encyst, increasing their survival and stimulating germination. Dijksterhuis and Deacon (8) showed that mechanical agitation induced rapid zoospore encystment of $P$. palmivora, followed by germination of most of them 90 min later. Agitation due to spraying with pressurized air may have had a protective effect at lower pressures that was not induced at higher pressures. Carbon dioxide used as a pressure source may have interfered with the agitation-induced encystment, accounting for the lack of differences between the spray and pour treatments when $\mathrm{CO}_{2}$ was used at lower pressures. At the highest pressure (630 $\mathrm{kPa}), \mathrm{CO}_{2}$ spray treatments resulted in very low colony counts. $\mathrm{CO}_{2}$ has been investigated for inactivation of certain microorganisms for food preservation, but at very high pressures $(2,7,34)$. Park et al. (23) completely inactivated one bacterial and two fungal species by first subjecting them to $\mathrm{CO}_{2}$ at the relatively low pressures of 170 to $380 \mathrm{kPa}$, followed by an additional very-high-pressure treatment of $500 \mathrm{MPa}$ for $15 \mathrm{~min}$. They also found a low level of inactivation of Fusarium oxysporum with a 20-min treatment of $\mathrm{CO}_{2}$ at $380 \mathrm{kPa}$ without the additional high-pressure treatment. They speculated that the $\mathrm{CO}_{2}$ treatment may cause a decrease in cellular $\mathrm{pH}$ and possibly a decrease in membrane permeability. Possibly, $\mathrm{CO}_{2}$ pressurization also is affecting membrane permeability of Phytophthora zoospores, making them more susceptible to disruption due to physical forces. More work is needed to determine the actual cause of damage due to pressurized $\mathrm{CO}_{2}$.

In conclusion, application pressures of zoospore suspension along with forces associated with spraying and exposure to pressurized $\mathrm{CO}_{2}$ act to reduce the survival of the spores and resulting foliage blight levels. Investigation and manipulation of these factors to inactivate zoospores suspended in recycling nursery irrigation systems are subjects of an ongoing study. Development of an alternative methodology for controlling zoospores in irrigation water utilizing an inexpensive adaptation to the irrigation system is the ultimate goal.

\section{ACKNOWLEDGMENTS}

This is project was supported in part by a grant from the Virginia Nursery and Landscape Association to C. X. Hong.

\section{LITERATURE CITED}

1. Ali-Shtayeh, M. S., MacDonald, J. D., and Kabashima, J. 1991. A method for using commercial ELISA tests to detect zoospores of Phytophthora and Pythium species in irrigation water. Plant Dis. 75:305-311.
2. Ballestra, P., Silva, A. A. D., and Cuq, J. L. 1996. Inactivation of Escherichia coli by carbon dioxide under pressure. J. Food Sci. 61:829-836.

3. Benson, D. M., and Broembsen, S. L. 2001. Phytophthora root rot and dieback. Pages 5256 in: Diseases of Woody Ornamentals and Trees in Nurseries. R. K. Jones and D. M. Benson. American Phytopathological Society Press. St. Paul, MN.

4. Bush, E. A., Hong, C. X., and Stromberg, E. L. 2003. Fluctuations of Phytophthora and Pythium spp. in components of a recycling irrigation system. Plant Dis. 87:1500-1506.

5. Charlton, N. D., and von Broembsen, S. L. 2000. Survival, settling and lateral dispersal of encysted zoospores of Phytophthora spp. in captured irrigation runoff. (Abstr.) Phytopathology 90:S13.

6. Cohn, D. R., and Hong, C. X. 2003. Efficacy of ultraviolet irradiance for disinfesting recycled irrigation water. (Abstr.) Phytopathology 93:S123.

7. Daniels, J. A., Krishnamurthi, R., and Rizvi, S. S. A. 1985. A review of effect of carbon dioxide on microbial growth and food quality. J. Food Prot. 48:532-537.

8. Dijksterhuis, J., and Deacon, J. W. 2003. Defective zoospore encystment and suppressed cyst germination of Phytophthora palmivora caused by transient leaching treatments. Antonie Leeuwenhoek 83:235-243.

9. Downey, D., Giles, D. K., Delwiche, M. J., and MacDonald, J. D. 1998. Development and validation of a general model for predicting biological efficacy of UV reactors against plant pathogens in irrigation water. Trans. ASAE 41:849-857.

10. Ewart, J. M., and Chrimes, J. R. 1980. Effects of chlorine and ultraviolet light in disease control in NFT. Acta Hortic. 98:317-323.

11. Ferguson, A. J., and Jeffers, S. N. 1999. Detecting multiple species of Phytophthora in container mixes from ornamental crop nurseries. Plant Dis. 83:1129-1136.

12. Furukawa, S., Matsuoka, A., Nakamichi, Y., Kato, T., Shimoda, M., and Hayakawa, I. 2001. Inactivation of spores of three Bacillus strains by low hydrostatic pressure (LHP) treatment. J. Fac. Agric. Kyushu 45:525-530.

13. Gilbert, G. S., Handelsman, J., and Parke, J. L. 1990. Role of ammonia and calcium in lysis of zoospores of Phytophthora cactorum by Bacillus cereus strain UW85. Exp. Mycol. 14:1-8.

14. Heald, C. M., and Johnson, A. W. 1969. Survival and infectivity of nematodes after passing through an overhead sprinkler irrigation system. J. Nematol. 1:290.

15. Hong, C. X., Bush, E. A., Richardson, P. A., and Stromberg, E. L. 2001. The major deterrent to recycling irrigation water in nursery and greenhouse operations despite lack of alternatives for limiting nonpoint source pollution. Pages 72-77 in: Proc. 1st Va. Water Res. Symp.

16. Hong, C. X., and Moorman, G. W. 2005. Plant pathogens in irrigation water: challenges and opportunities. Crit. Rev. Plant Sci. 24:189-208.

17. Hong, C. X., Richardson, P. A., and Kong, P. 2002. Comparison of membrane filters as a tool for isolating pythiaceous species from irrigation water. Phytopathology 92:610-616.

18. Hong, C. X., Richardson, P. A., Kong, P., and Bush, E. A. 2003. Efficacy of chlorine on multiple species of Phytophthora in recycled nursery irrigation water. Plant Dis. 87:1183-1189.

19. Hoover, D. G. 1993. Pressure effects on biological systems. Food Technol. 47:150-155.
20. Lauderdale, C. C., and Jones, R. K. 1997. Monitoring irrigation ponds for Phytophthora sp. Proc. South. Nursery Assoc. Res. Conf. 42:225-226.

21. MacDonald, J. D., Ali-Shtayeh, M. S., Kabashima, J., and Stites, J. 1994. Occurrence of Phytophthora species in recirculated nursery irrigation effluents. Plant Dis. 78:607-611.

22. Palhano, F. L., Vilches, T. T. B., Santos, R. B., Orlando, M. T. D., Ventura, J. A., and Fernandes, P. M. B. 2004. Inactivation of Colletotrichum gloeosporioides spores by high hydrostatic pressure combined with citral or lemongrass essential oil. Int. J. Food Microbiol. 95:61-66.

23. Park, S. J., Park, H. W., and Park, J. 2003. Inactivation kinetics of food poisoning microorganisms by carbon dioxide and high hydrostatic pressure. J. Food Sci. 68:976-981.

24. Pittis, J. E., and Colhoun, J. 1984. Isolation and identification of pythiaceous fungi from irrigation water and their pathogenicity to Antirrhinum, tomato and Chamaecyparis lawsoniana. Phytopathol. Z. 110:301-318.

25. Robinson, I., and Adams, R. P. 1978. Ultraviolet treatment of contaminated irrigation water and its effect on the bacteriological quality of celery at harvest. J. Appl. Bacteriol. 45:8390.

26. Runia, W. T., Michielsen, J. M. G. P., van Kuik, A. J., and van Os, E. A. 1997. Elimination of root-infecting pathogens in recirculating water by slow sand filtration. Pages 395407 in: Proc. 9th. Int. Congr. Soilless Culture.

27. Shokes, F. F., and McCarter, S. M. 1979. Occurrence, dissemination, and survival of plant pathogens in surface irrigation ponds in southern Georgia. Phytopathology 69:510-516.

28. Stanghellini, M. E., Kim, D. H., Rasmussen, S. L., and Rorabaugh, P. A. 1996. Control of root rot of peppers caused by Phytophthora capsici with a nonionic surfactant. Plant Dis. 80:11131116

29. Stanghellini, M. E., Rasmussen, S. L., Kim, D. H., and Rorabaugh, P. A. 1996. Efficacy of nonionic surfactants in the control of zoospore spread of Pythium aphanidermatum in a recirculating hydroponic system. Plant Dis. 80:422428.

30. Stanghellini, M. E., and Tomlinson, J. A. 1987. Inhibitory and lytic effects of a nonionic surfactant on various asexual stages in the life cycle of Pythium and Phytophthora species. Phytopathology 77:112-114.

31. Thomson, S. V., and Allen, R. M. 1974. Occurrence of Phytophthora species and other potential plant pathogens in recycled irrigation water. Plant Dis. Rep. 58:945-949.

32. van Os, E. A., Amsing, J. J., van Kuik, A. J., and Willers, H. 1999. Slow sand filtration: a potential method for the elimination of pathogens and nematodes in recirculating nutrien solutions from glasshouse-grown crops. Acta Hortic. 481:519-525.

33. von Broembsen, S. L., and Wilson, S. K. 1998. Occurrence of Phytophthora spp. in nursery runoff and recycled irrigation water. (Abstr.) Phytopathology 88:S92.

34. Watanabe, T., Furukawa, S., Hirata, J., Koyama, T., Ogihara, H., and Yamasaki, M. 2003. Inactivation of Geobacillus stearothermophilus spores by high-pressure carbon dioxide treatment Appl. Environ. Microbiol. 69:7124-7129.

35. Yamamoto, H., Terada, T., Naganawa, T., and Tatsuyama, K. 1990. Disinfectious effect of ozonation on water infested with several rootinfecting pathogens. Ann. Phytopathol. Soc. Jpn. 56:250-251. 